\title{
Introduction to Part II
}

\author{
Simona Giordano
}

Part II of this volume focuses on the regulation of science. Particularly with regard to science that directly affects or uses human materials (tissues and cells) or human beings (not only fully conscious humans, but also embryos, foetuses or humans without higher brain functions, or in persistent vegetative states, or minimally conscious human beings), two types of concerns are frequently raised. The first is that scientists may misuse the materials, or mistreat the research subjects - even those who may be unable to suffer may still, according to some views at least, have their dignity eroded or violated. Some see in human life - any human life, including human biospecimens, such as tissues or cells - something that bears an intrinsic dignity or value, and from this perspective utilising these materials is inherently suspicious, no matter what the expected societal benefits might be. The fact that some forms of research may yield significant financial rewards (e.g. for pharmaceutical companies) may raise further worries. And the fact that even a tissue or a cell can reveal information that may be significant in different contexts and for different people (in forensics for example, or for genetic relatives) raises important questions about how different interests may be or should be balanced.

The second, somehow contrary concern, is that stifling regulation might be shaped by political norms, or by ideologies that might either be dominant or, even if not dominant numerically, powerful enough to skew public opinion and political debate, with resulting harm to science itself, to scientists and, more importantly, to societal benefits. If the loss of societal benefit is a form of harm, then arguably certain political norms and regulatory constraints are harmful; and if society is not an abstract entity but a sum of individuals, then societal harm, or loss of societal benefits, is not to be understood as abstract harm to an ideal entity, but as tangible harm to real individuals.

Scientific research is often perceived as a threat; medical sciences illustrate vividly the tension between the goals of scientific research and the long-term interests of society, on the one hand, and individual rights on the other. 
The need for regulation springs from an apprehension that is legitimate; but, as we shall see, it is legitimate only to an extent.

The discovery of the crimes committed by the Nazis in various concentration camps, not only against Jewish people but against many other groups, and the uncovering of similar crimes committed by seemingly reputable scientists in other countries, has marked science as suspect or even inherently dangerous. The involvement of physicists in the invention of nuclear power, which has then been used in war, calls into question the morality of scientific goals (or at least the morality of how scientific innovation can be used, and of how people come to be empowered to make decisions about how it is used).

The history of science is replete with such atrocities (Frewer and Schmidt 2007). We may remember the case of Hideyo Noguchi, employed in the 1920s at the Rockefeller Institute, who infected hundreds of patients in New York's hospitals with syphilis for 'research purposes' (Corbellini and Lalli 2016). During the early 1900s several hundred people were also infected with syphilis and other sexually transmitted diseases in Guatemala. The 'research subjects' included orphan children. We know of several other studies conducted in the US that involved the injection of cancerous cells and exposure to radioactive substances, including uranium, and of many other studies in microbiology conducted similarly in China, Great Britain, Sweden, Italy and Russia.

Well after the end of the Second World War, and well after the Nuremberg Trials and the publication of the Nuremberg Code on ethical research, the Tuskegee Syphilis Study threw further discredit on science. In this study several hundred ill people from the Afro-American community were denied available medical treatment in order to observe and document the natural progression of the disease. Around the same time, it became known that Saul Krugman, employed by New York University, infected mentally ill children with hepatitis. Krugman gathered the parents' consent for, allegedly, vaccinations, but in reality children were fed with food contaminated with the faeces of ill patients, and were in that manner infected and 'studied'. In the 1970s it became known to the public that the CIA had performed a number of studies (under a programme called MKULTRA) which involved psychological torture and the use of various drugs, particularly LSD, with the aim of developing methods of mind control and mechanisms for coping with interrogation. It is unknown how many people were tortured and murdered, as the CIA has destroyed large parts of the evidence.

It should be noted that, with some exceptions, the 'results' of most of these studies have not become a part of the scientific literature (Corbellini and Lalli 2016: 92), because they were not based on any methodology. Thus, arguably, this was not science: these were sheer murders.

In any case, these examples provide a picture of incredible brutality and perversion, in which many thousands of people were victims over the course of the twentieth century (Corbellini and Lalli 2016: 92). And, of course, 
though it does not go so far, professional misconduct in science is of concern - in the last decade or so we have seen cases of the falsification of results, publication bias, and scientific and medical fraud. It can be argued, looking at human history, that exploitation and persecution (let alone fraud), in the name of science, religion or politics, are not isolated incidents - they are common. Usually these actions are directed at those perceived as 'others' (racial others, religious others, non-humans, and so on), not worthy of moral concern and respect. There is thus reason to be worried about those who have the power to exploit and persecute, and to vex, discriminate and abuse.

There is a further reason to be worried. We may think that the so-called Nazi scientists were psychopaths; that those other scientists involved in gratuitous torture and murder were also psychopaths, affected by the delirium of grandeur and moral viciousness. Actually, it is possible that they were all 'normal people'. We know from a number of studies in psychology performed and repeated since the 1960s that many ordinary people, not afflicted by any mental disorder, not morally callous and not psychopaths, can be turned into torturers or even potential murderers in the right (or rather wrong) circumstances (Milgram 1974; Zimbardo 2007).

What does this mean? It means that apprehension about science, which inherently gives people more control over others, and over the environment, is legitimate at some level. Scientists (or murderers in that disguise) have tortured and abused and murdered other humans over the course of history and have created tools that could lead to the destruction of entire cities in seconds. However, the apprehension is misplaced - it is not science or knowledge per se that should worry us. It is ourselves; it is human nature that should worry us. We possess an ability to dehumanise others that leads us, in certain contexts, to become brutal.

However, not all humans utilise this ability to become cruel. We may not naturally be gifted with the ability to recognise that the 'different' is equally valuable morally - and in the wrong cultural conditions, this can lead to the worst atrocities of which humans may be capable. It is indeed important to bear this in mind - that in certain social or cultural contexts, humans, not only collectively, but each of us individually, have the ability to become cruel. But the right cultural conditions may on the contrary enhance our empathy, enable us to recognise others as equally valuable, or at least to raise questions about who should be the subject of our moral concern and respect (Pinker 2012; Corbellini and Lalli 2016). In short, it is not science itself that perpetrates atrocities; it is humans, under certain cultural conditions. It is thus imperative that the right cultural conditions are established, and with this in mind Part II of this volume attempts to reason around regulatory mechanisms.

During the twentieth century, developments in biomedical sciences, including molecular biology and genetics, revolutionised the way human life is understood. Reanimation techniques raise the fundamental, metaphysical question of when it is that a person is dead (and thus, when it is that 
we are alive). New frontiers in reproduction, particularly the possibility of producing humans in alternative ways (with donors' gametes, or with 'parts' of gametes donated by third parties, or even with cloning techniques) raise metaphysical and legal questions relating to personal identity and parental rights. During the second half of the twentieth century it even became possible to create human DNA (recombinant DNA - rDNA). It is interesting to note that it was the scientists who themselves had created rDNA who asked for a moratorium on the development of science in this area, prior to elaborating guidelines for the continuation of research with the Asilomar Conference in 1975.

Scientific research requires complex negotiation, as we will see, of values between citizens, scientists, medical doctors, researchers, patients, research participants and society as a whole. Indeed, one could include non-humans in the pool of those whose interests should be considered in these negotiations. Political and scientific agendas may be at odds with one other. Many of the contributors here point this out. Political agendas are often inspired by the views of the majority in liberal democracies, or at least by the goal of finding viable compromises in areas in which views are starkly dialectical and dichotomous; and these two goals or aspirations may not be consistent with the aims and methods of scientific enquiry. Yet at a perhaps more profound level, politics and science should both be committed to the same ultimate goals: they should both serve people and society as a whole.

Thus, the questions posed in Part II of the collection are: how can politics better serve science? And how can science inform politics? The answers to these questions depend in part, of course, on the moral legitimacy and plausibility of specific scientific enterprises. Politics should not serve science if the purposes of science are malevolent, and of course politics should condemn moral turpitude in science, both in purposes and methods. But these answers also depend on other things: on how conflicts of interests may be resolved, for example; or on how accountability, through, for example, valid and reliable peer-review systems, may be achieved.

On this point, Ballabeni and Danovi (Chapter 9) highlight the pitfalls of the current peer-review system, established worldwide but rather outdated, they argue, and suggest alternative modes of adjudication regarding funding and the assessment of scientific validity; they also propose alternative modes of publishing structures in order to transform the communication of science to the general public, particularly by making use of the cheap and easily accessible World Wide Web. What seems to emerge from their analysis is that science and politics can reconcile their inherent tensions, but this requires the ambition to effect radical transformations to the cultural framework in which scientists operate.

Some of the authors in Part II argue that public or political recognition of the value of science raises specific political obligations. For example, Mertes (Chapter 11) suggests that the societal values that are lost through 
the tight regulation and prohibition of embryological research place an obligation on politicians to legislate, and legislate in one specific direction, the only one that is ethically defensible given the benefits and the losses at stake. Similarly, Cappato in Chapter 12 considers the tension between politics, regulation and science, in particular in the case of narcotic drugs. He argues that prohibition of the personal use of narcotic drugs, even if intended to protect citizens from the hideous consequences of addiction and to protect vulnerable members of society from exploitation (in the form of being caught in the net of illicit drug trafficking), still deprives society of important goods. Prohibition of narcotics has had as a by-product a comprehensive limitation on science, outlawing or heavily obstructing the medical use of illicit plants and substances, and research into their effects and potential. This approach has a number of consequences: one is that research on narcotics is inadvertently in this way 'handed over' to organised crime, which is more and more able to provide cheaper and more 'effective' (as well as more dangerous) recreational drugs. Second, it criminalises those in the grip of terminal or chronic illnesses, afflicted often by long-lasting and sometimes intractable pain, some of whom may find in opioids a valid form of pain control. Finally, prohibition results in a violation of fundamental human rights, Cappato argues. Scientific research and the enjoyment of its fruits are a human right: this human right is protected and defended by a number of UN declarations and conventions. To abide by the rights enshrined in the UN declarations and conventions, prohibitions should be radically reformed. Recent studies on the medical use of cannabis derivatives as well as some of the latest research on LSD and other controlled substances could be, if supported and promoted, a turning point in the matter.

Others highlight that there are other values at stake, not just the value of extending human life and ameliorating its quality. Baldoli and Radaelli (Chapter 14) explain how the precautionary principle is used to preserve and protect these other values, which can also be encompassed in the wider notion of societal benefits. Boggio and Romano (Chapter 10) discuss how freedom of research is codified in human rights law in the form of a human right to science, and articulate ways in which the right to science can be mobilised politically and judicially.

Scientific research, as has been pointed out earlier, is often perceived as a threat. However, Corbellini and Sirgiovanni (Chapter 13) point out that scientific research, and particularly scientific method, can actually protect us from this perceived threat. And by arguing this, they offer further considerations on how the tensions between politics and science can be resolved. They note that the prevailing theory about the relationship between science and human freedom is that science contributes to human autonomy or self-determination through the discovery of natural laws and by providing devices to solve practical problems in order to stimulate economic growth. 
Simply put, the more we know about the world, the more we understand it, the better we can live in it, control it, and make autonomous, selfdetermined decisions about how we wish to conduct our lives. Countries in which science flourishes also tend to be middle- and high-income countries, and there is thus a positive association between economic growth and scientific freedom. But they note that a more likely hypothesis is that the invention and use of the scientific method in the modern age introduced into human communities a new way of thinking, which allowed a significant percentage of people to go beyond a set of cognitive and emotional biases that we inherited from our evolutionary ancestors, who, however, lived in simpler environments. In this way some psychological tools have been made available to an increasing number of people, prevalently in the Western world. These tools allowed human beings to achieve important cognitive and moral improvements, which made liberal and democratic governments possible: thus in a sense it is science that makes liberal democracies possible, and not liberal democracies that make (or should make) the progress of science possible. Science does not simply produce societal benefits that are tangible and usable (new vaccines, new forms of transplants); it also makes people more cooperative, less self-centred, less impulsive and more selfcontrolled (in the sense of autonomous), even in contexts that tend not to facilitate these behaviours.

One thing seems to follow from this: namely that politics should somehow recognise that it is science (in its many forms, and in its wider sense of the pursuit of knowledge through the systematic analysis of facts and reasoning around those) that generates and holds together, historically, psychologically and logically, the fabric of modern liberal democracies. Woolley (Chapter 15) points out that it is thus necessary to enhance the visibility of the research enterprise in society to ensure that decision-making by policymakers is responsive to scientific progress. Woolley calls on scientists to engage with non-scientists and actively advocate the value of research as a matter of public and national priority. When we talk about the right to science, or about freedom of scientific research, we should remember how the circulation and dissemination of scientific culture (including humanistic culture) can in itself promote the flourishing of society as a whole, and can even guarantee greater peace, in that it allows us to overcome certain moral and psychological boundaries (as Piccirillo notes in Chapter 8 of Part I) and recognise the equal value of others.

There are many specific areas of the regulation of science that this volume has left unexplored - genetics and genomics, research using non-human animals, biology (particularly synthetic biology) - and it will be interesting to evaluate how regulatory mechanisms will apply to artificial intelligence. Our aim is not to explore all areas of science that could give raise to ethical or political issues. Our hope is rather to stimulate reflection on important issues that affect many of us, and on the complexities inherent in the relationship between scientific research and regulatory mechanisms. 


\section{References}

Corbellini, G., and Lalli, C. (2016), Bioetica per perplessi, Milan: Mondadori. Frewer, S. A., and Schmidt, U. (eds) (2007), History and Theory of Human Experimentation: The Declaration of Helsinki and Modern Medical Ethics, Stuttgart: Franz Steiner Verlag.

Milgram, S. (1974), Obedience to Authority: An Experimental View, London: Tavistock.

Pinker, S. (2012), The Better Angels of Our Nature: Why Violence Has Declined, New York: Penguin.

Zimbardo, P. G. (2007), The Lucifer Effect: Understanding How Good People Turn Evil, New York: Random House. 